\title{
Comparative Study of Sealing Ability of Different Filling Materials for Root End: An In Vitro Evaluation
}

\author{
Shagun Bhatia ${ }^{1}$ Ankush Jain ${ }^{2}$ Himanshu Sood ${ }^{3} \quad$ Kanu Jain ${ }^{4}$ \\ ${ }^{1}$ Department of Conservative Dentistry and Endodontics, Luxmi Bai \\ Institute of Dental Sciences and Hospital, Patiala, Punjab, India \\ 2Periodontics and Oral Implantology, Private Practitioner, Patiala, \\ Punjab, India \\ ${ }^{3}$ Department of Conservative Dentistry and Endodontics, Desh \\ Bhagat Dental College, Mandi Gobindgarh, Punjab, India \\ ${ }^{4}$ Department of Oral Pathology, Maharaja Ganga Singh Dental \\ College and Research Centre, Sri Ganganagar, Rajasthan, India
}

\begin{abstract}
Address for correspondence Kanu Jain, MDS, Department of Oral and Maxillofacial Pathology, Maharaja Ganga Singh Dental College and Research Centre, Sri Ganganagar, Rajasthan 335002, India (e-mail: drkanupriyajain@gmail.com).
\end{abstract}

Dent J Adv Stud:2021;9:22-26

\author{
Abstract \\ Keywords \\ - intermediate \\ restorative material \\ - mineral trioxide \\ aggregate \\ - Portland cement
}

Introduction Failure in surgical endodontic techniques can occur most commonly due to improper seal in the apical region. The root-end filling material used should not allow the contamination of the periapical tissue. The aim of the present study was to compare the ability of white mineral trioxide aggregate (MTA), white Portland cement (PC) and intermediate restorative material (IRM) for sealing root-end by dye leakage test.

Materials and Methods 120 teeth with single root were prepared through instruments. Following obturation, the apex was cut, and a cavity was made. Then, the teeth were divided into four groups (Group I: MTA, Group II: white PC, Group III: IRM, Group IV: control). Cavities made at apex in the first three groups were then filled with the respective materials. Exposure to the dye, India Ink, was then done for a time period of 72 hours. The depth of penetration of dye inside the whole root was then evaluated with a magnification of 16X under stereomicroscope in vitro.

Result MTA showed statistically significant difference in sealing ability $(p<0.05)$ as compared with other materials.

Conclusion MTA cement showed better sealing ability. It is an ideal retrograde filling material, because it is a biocompatible material and has a good marginal adaptation as compared with PC which, in turn, showed better sealing ability than IRM.

\section{Introduction}

Obturation in all three dimensions, apically, coronally, and laterally, is imperative for a successful endodontic treatment ${ }^{1}$. A good apical seal is responsible for preventing the egress of microorganisms. The success of endodontic therapy rests on the triad of proper diagnosis, thorough debridement of pulpal space, and obturation of root canals in all the three dimensions. The aim of root canal therapy is to provide a fluid tight seal to prevent communication of intraradicular space with tissues in the periapical region. ${ }^{2}$

A good root-end filling material thus aims at rendering an apical seal that will not allow bacterial movement and

\section{published online}

September 17, 2020
DOI https://doi.org/

10.1055/s-0040-1716926

ISSN 2321-1482. diffusion of their products from within the canal to periapical tissues and from periapex into the root canal system. ${ }^{3}$ It has been shown by many researchers that an adequate apical seal is one of the significant factors to achieve successful completion of endodontic surgery.

Root-end filling materials should be capable of closely adapting to walls of dentin at prepared root-end which, in turn, leads to achieve an adequate apical seal. Moreover, it must be biocompatible to the tissues in the periapical region. It should also be nonresorbable, impermeable to dissolution, and possess good handling properties. ${ }^{4} \mathrm{~A}$ plethora of materials have been in use from long as root-end filling. These

(C2020. Bhojia Dental College and Hospital affiliated to Himachal Pradesh University.

This is an open access article published by Thieme under the terms of the Creative Commons Attribution-NonDerivative-NonCommercial-License, permitting copying and reproduction so long as the original work is given appropriate credit. Contents may not be used for commercial purposes, or adapted, remixed, transformed or built upon. (https://creativecommons.org/licenses/by-nc-nd/4.0/).

Thieme Medical and Scientific Publishers Pvt. Ltd. A-12, 2nd Floor, Sector 2, Noida-201301 UP, India 
include intermediate restorative material (IRM), amalgam, cavit, super ethoxy benzoic acid, glass ionomer cement (GIC), composite resin, and carboxylate cement ${ }^{5}$

A very commonly employed method for evaluation of marginal seal is penetration of dye. The attributable properties are their ease of storage, safety factor, and inexpensive materials which can be subjected to quantitative assessment. Some of the useful dyes in this regard are silver nitrate dye, basic fuchsin dye, Indian ink, Rhodamine B, and methylene blue dye. For the assessment of leakage, it is important to select a dye which is as small in size as possible, so that it can pass through the smallest of discrepancies at the tooth-restoration interface. Rhodamine B dye is preferred as its molecular size is relatively small measuring approximately 1 nanometer. ${ }^{6}$

Mineral trioxide aggregate (MTA) is the material which is recommended as a material for filling radicular ends and repair of perforations. This study aimed at comparing the sealing capability of MTA, Portland cement (PC), and IRM as potential materials for filling root-ends and finding out which material is best out of the three.

\section{Materials and Methods}

This study was conducted at Darshan Dental College and Research Institute, Udaipur, from August 2015 to January 2016 as a prospective study. For the current study, a total of 120 extracted human maxillary central incisors were included. All of the teeth were cleaned thoroughly, following which normal saline was used to store them. The teeth selected were the ones with single canal, without curvatures, a complete apical end, absence of cracks when examined up to magnification of four times, absence of root caries, along with absence of calcification or any type of resorption. Radiographs were taken preoperatively to visualize the canals for their interior. Once the preparation for access was done, a $10 \mathrm{~K}$-file with size 10 (Dentsply Maillefer, Ballaigues, Switzerland) was put inside the canal till its tip became clearly imperceptible at the apical foramen. About $0.5 \mathrm{~mm}$ was subtracted from this length to conclude the working length. This file served as patent file as well as preparation of canal. Size 20 was the maximum size that initial file fitted at $\leq 1 \mathrm{~mm}$ from the apex which were included for study. Those roots which did not fit this size criteria were substituted with new roots. A step back method was employed to prepare canals, with file size 40 being set as the master file size. $3 \%$ sodium hypochlorite $(\mathrm{NaOCl})$ was used for purpose of irrigation of canals in between the process of instrumentation. $5 \mathrm{~mL}$ of $3 \% \mathrm{NaOCl}$, followed by irrigation with $5 \mathrm{~mL}$ of $17 \%$ ethylenediaminetetraacetic acid (EDTA) solution (Pulpdent Corporation, USA) and a rinse with $5 \mathrm{~mL}$ of $3 \% \mathrm{NaOCl}$ were used as final steps. Gutta-percha along with AH plus sealer (Dentsply Maillefer, Ballaigeus, Swaziland) was then brought into canals for obturation, using lateral compaction method. A heat carrier was used to remove any extra gutta-percha, followed by vertical condensation using hand plugger at the openings of canals. Glass ionomer material was filled after radiographic confirmation for good obturation was done. Storage of the final specimens for 7 days was done at a temperature of $37 \pm 1^{\circ} \mathrm{C}$ and $100 \%$ relative humidity.

Four groups of 30 teeth in each were made as described above. With the help of a cross-cut fissure bur (556, Mani, Japan), the apical $3 \mathrm{~mm}$ of the obturated roots was cut perpendicular to the longitudinal axis. Using a straight fissure diamond burr (SF 41, Mani, Japan), a cavity in retrograde direction was made, using standard dimensions of depth $3 \mathrm{~mm}$ and width $0.8 \mathrm{~mm} .^{7}$ The cavities were dried, following irrigation with EDTA and saline. Groups I, II and III were then filled at the radicular ends with white MTA (ProRoot MTA, Dentsply Tulsa, OK, USA), white PC (JK White cement), and IRM (Caulk Dentsply Milford, DE, USA), respectively. As per the instructions provided by manufacturer, the three materials were filled in the cavities with the help of Messing's carrier. A ratio of 3:1 was utilized to mix PC with distilled water, following which it was used to fill the prepared root end cavity, using amalgam carrier, and thoroughly condensed with the help of finger plugger. In Group IV, no experimental material was placed in root-end cavities.

A wet gauze was used to wrap the roots. Then, all the samples were incubated at $37^{\circ} \mathrm{C}$ for 48 hours to ensure the complete setting of materials. In groups I, II and III, a coating of nail varnish was applied over all the roots, excluding $1 \mathrm{~mm}$ of resected apex which was left to dry. India ink dye sipping method was employed to check for any leakage at apex. This was performed by leaving the apical third of root in dye solution for 72 hours at temperature of $37^{\circ} \mathrm{C}$ and $100 \%$ humidity. After taking out the specimens, they were rinsed thoroughly beneath tap water and left to dry. Taking diamond discs along with cold water irrigation, all the blocks were cut into two halves vertically in buccolingual direction.

The extent of apical dye penetration into root canal from root apex was measured in micrometers using stereomicroscope (NSZT - 44E Radical Instruments) (20x magnification) in all the four groups. Images were then captured using DSLR camera (Canon) and later imported in Adobe Photoshop CS2 software (Adobe Corporation, United States) (-Fig. 1).
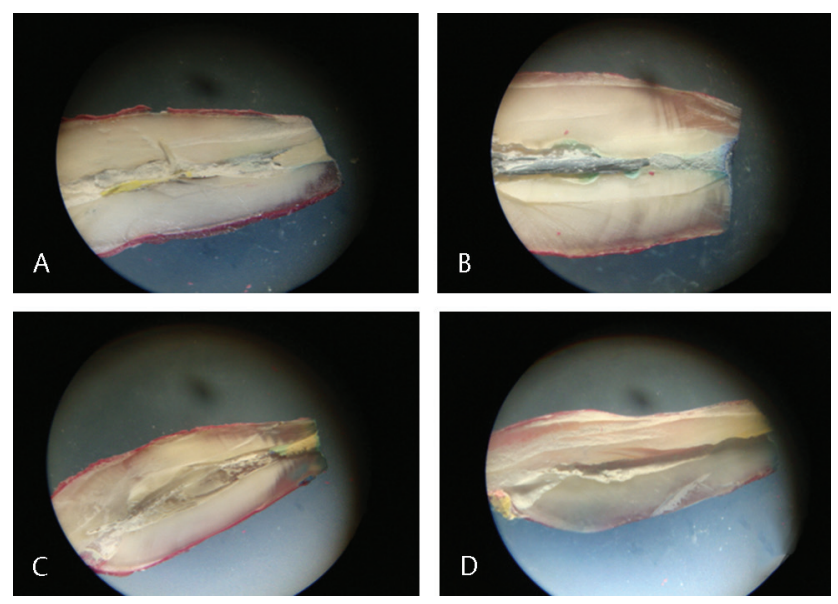

Fig. 1 Photograph showing dye penetration in (A) Group I (mineral trioxide aggregate [MTA]), (B) Group II (Portland cement [PC]), (C) Group III (intermediate restorative material [IRM]), (D) Group IV (control). 
Table 1 Mean value of marginal leakage

\begin{tabular}{|l|l|l|l|l|}
\hline & Number & M & SD & SE \\
\hline I-MTA & 30 & 0.487 & 0.3159 & 0.0577 \\
\hline II-PC & 30 & 0.847 & 0.2849 & 0.0520 \\
\hline III-IRM & 30 & 1.657 & 0.5817 & 0.1062 \\
\hline IV-Control & 30 & 3.000 & 0.0000 & 0.0000 \\
\hline Total & 120 & 1.497 & 1.0327 & 0.0943 \\
\hline
\end{tabular}

Abbreviations: IRM, intermediate restorative material; M, Mean; MTA, mineral trioxide aggregate; PC, Portland cement; SD, standard deviation; SE, standard error.

Note: Extent of dye penetration (microleakage) in millimeters (mm).

Table 2 Comparison of dye penetration in different groups

\begin{tabular}{|l|l|l|l|l|}
\hline I & J & $\begin{array}{l}\text { MD } \\
(I-J)\end{array}$ & SE & $p$-Value \\
\hline \multirow{2}{*}{ Group I-MTA } & Group II-PC & $-0.3600^{\text {a }}$ & 0.0930 & 0.001 \\
\cline { 2 - 5 } & Group III-IRM & $-1.1700^{\text {a }}$ & 0.0930 & 0.000 \\
\hline \multirow{2}{*}{ Group II-PC } & Group I-MTA & $0.3600^{\text {a }}$ & 0.0930 & 0.001 \\
\cline { 2 - 5 } & Group III-IRM & $-0.8100^{\text {a }}$ & 0.0930 & 0.000 \\
\hline \multirow{2}{*}{ Group III-IRM } & Group I-MTA & $1.1700^{\text {a }}$ & 0.0930 & 0.000 \\
\cline { 2 - 5 } & Group II-PC & $0.8100^{\text {a }}$ & 0.0930 & 0.000 \\
\hline
\end{tabular}

Abbreviations: IRM, intermediate restorative material; MD, mean difference; MTA, mineral trioxide aggregate; PC, Portland cement; SE, standard error.

Note: Multiple comparisons, ANOVA.

Dependent variable: Extent of dye penetration (microleakage) in millimeters $(\mathrm{mm})$.

aSignificant values.

The depth up to which dye penetrated was measured using a metallic ruler. This was done at two levels, at interface of material filled end and walls of canal on each half of root. Results were compared and analyzed through different statistical methods. First, mean along with standard deviation (SD) were calculated to be followed by Tukey's test and oneway analysis of variance (ANOVA). A $p$ value $<0.05$ was fixed as statistically significant value.

\section{Results}

Group IV in all the retrograde cavities had maximum amount of microleakage. This observation indicates that root-end should always be filled to avoid microleakage. Descriptive statistics of microleakage for groups I, II, III and IV are shown (-Table 1). A significant difference level of leached dye is obvious in comparison of the three groups (ANOVA) $(p=0.001)(-$ Table 2$)$.

\section{Discussion}

Important objectives of nonsurgical treatment of root canals are expulsion of the irritants, followed by an obliteration complete enough in three dimensions. ${ }^{7}$ An institution of perfect seal at apex is mandatory to prevent leakage and ensure success of treatment. ${ }^{8}$
The cases in which conventional endodontic treatment fails or retreatment is not feasible, for example, in calcified canals, root canals with broken instruments, iatrogenic perforations, etc., the surgical endodontic treatment is indicated. ${ }^{3}$ This procedure involves debridement and curettage of periradicular lesion from pathological tissues, root apex disclosure, sectioning of root end, and filling it with material. ${ }^{9}$

A good adherence of material to the walls is necessary to dictate adequate sealing. This material has to be nontoxic, with display of good tolerance by surrounding tissues and should be able to promote healing. In addition, it must be noncorrosive, nonstaining, easily modifiable, electrochemically inactive, and radiopaque. Other desirable qualities are dimensional stability, being impervious to moisture, and nonabsorbable. ${ }^{10,11}$

Several substances that have been used include amalgam, composite resin, gutta-percha, cavit, ZOE cement, GIC, polycarboxylate cement, IRM, and gold foil. ${ }^{4}$ Amalgam is unsuitable, as it can corrode, can exude mercury, and is quite sensitive to moisture. ${ }^{12}$ IRM is a polymer-reinforced zinc oxide eugenol composition material. It has a sedative-like property on a hypersensitive tooth pulp and a good thermal insulator, excellent abrasion resistance, good sealing properties, and less solubility. MTA is a new class of restorative material which was developed in the 1990s by Mohammad Torabinejad..$^{11}$ In 1998, the US Food and Drug Administration (ProRoot MTA, Dentsply Tulsa, Tulsa, OK) gave approval to use it for endodontics purpose. ${ }^{13,14}$ It constitutes calcium oxide (50-75\%) and silicon dioxide (15-25\%) which makes up 70 to $95 \%$ of the cement. On mixing, they liberate dicalcium and tricalcium silicates, tetracalciumaluminoferrite, and tricalcium silicate. A gel of silicate is form when water is added to it. Bismuth oxide serves as radiopacifier for diagnosis in radiographs. ${ }^{15}$ MTA is not only biocompatible but also holds a great capacity to expedite tissue regeneration. ${ }^{16} \mathrm{PC}$, a material used in civil engineering, was advocated for retrograde restoration.

MTA and PC have been shown to be quite similar macroscopically and under microscope. ${ }^{17} \mathrm{PC}$ has also been said to carry same material composition as MTA, with the only exception that it does not contain bismuth oxide, which is why it is radiolucent. ${ }^{18}$ This present research was undertaken for stereomicroscopic analysis of root end closure capability of three materials, namely, MTA, PC and IRM through calculation of extent of penetration of dye. According to the findings obtained, it was observed that the maximum mean dye penetration of 3000.00 $\mu \mathrm{m}$ was recorded in Group IV (control group), whereas the minimum mean dye penetration of $0.487 \mathrm{~mm}$ was recorded in Group I (MTA cement). Group I (MTA) when compared statistically with Group II (PC) and Group III (IRM), the mean scores were lowest and significant statistically ( $\mathrm{p}<.05)$ and mean value was 0.487 . According to the study done by Valera et al (2006), ${ }^{19}$ MTA shows less microleakage than PC.

The observations from this research shows agreement to those shown by Dammaschke and colleagues. ${ }^{20}$ They 
observed that MTA has uniform and smaller particles, whereas PC exhibits nonuniform and wide range of particle sizes. Therefore, MTA can be easily and evenly condensed into the cavity and thus exhibits less microleakage as compared with PC.

Islam et $\mathrm{al}^{21}$ found that $\mathrm{PC}$ has significantly greater dimensional change and lower compressive strength as compared with MTA. All of these factors contribute to more microleakage in PC. Danesh et $\mathrm{al}^{22}$ also found that PC has significantly lower microhardness and more solubility, thus resulting in more microleakage. Torabinejad et $\mathrm{al}^{23}$ also compared the leakage of bacteria to assess apical closure shown by MTA, IRM, super EBA, and amalgam. It inferred that roots which were filled with IRM showed early microleakage as compared with the MTA. Martell and Chandler $^{24}$ also concluded that MTA provides a superior seal in root-end restorations as compared with IRM and Super EBA by electrical and dye leakage test. Soundappan et $\mathrm{al}^{25}$ also concluded that MTA has a better marginal adaptation as compared with IRM at different levels.

Therefore, the findings from our research comes in congruence with the above shown results. Group II (white PC) recorded average dye penetration $(0.847 \mathrm{~mm})$ which is less when compared with Group III (IRM) $(1.657 \mathrm{~mm})$. Control group (Group IV) showed apical leak in full length of cavity, that is, of $3000.00 \mu \mathrm{m}$, thus indicating the need of fill at radicular end. In the present study, minimum dye leakage was recorded for Group I $(0.487 \mathrm{~mm})$, followed by Group II (0.847 mm), Group III (1.657 mm) and Group IV (3.00 mm). By applying one-way ANOVA, mean dye penetration difference came out to be significant statistically $(p<0.05)$. Thus, from the present research, an inference can be drawn that MTA can be considered a material of best sealing ability to do fill at the root-end.

\section{Conclusion}

MTA cement showed superior apical seal over other two substances. It is an ideal retrograde filling material because it is a biocompatible material and has a good marginal adaptation as compared with PC which, in turn, showed greater closure property over IRM. PC also has potential attributable to apparently similar features with MTA. We recommend that more research related to assessment of biocompatibility can validate PC as a probable candidate for use in endodontics.

\section{Conflict of Interest}

None declared.

\section{References}

1 Adel M, Nima MM, Kojoori SS, Oliaie HN, Naghavi N, Asgary S, Comparison of endodontic biomaterials as apical barriers in simulated open apices. Int Sch Res Net 2012. Doi: $10.5402 \% 2 F 2012 \% 2 F 359873$
2 Bortoluzzi EA, Broon NJ, Bramante CM. Garcia RB, de Moraes IG, Bernardineli N. Sealing ability of MTA and radiopaque Portland cement with or without calcium chloride for root-end filling. J Endod 2006;32(9):897-900

3 Pereira CL, Cenci MS, Demarco FF. Sealing ability of MTA, Super EBA, Vitremer and amalgam as root-end filling materials. Braz Oral Res 2004;18(4):317-321

4 Maltezos C, Glickman GN, Ezzo P, He J. Comparison of the sealing of Resilon, Pro Root MTA, and Super-EBA as root-end filling materials: a bacterial leakage study. J Endod 2006;32(4):324-327

5 Vogt BF, Xavier CB, Demarco FF, Padilha MS. Dentin penetrability evaluation of three different dyes in root-end cavities filled with mineral trioxide aggregate (MTA) Braz Oral Res 2006;20(2):132-136

6 El Sayed M, Saeed M. In vitro comparative study of sealing ability of Diadent BioAggregate and other root-end filling materials. J Conserv Dent 2012;15(3):249-252

7 Bidar M, Moradi S, Jafarzadeh H, Bidad S. Comparative SEM study of the marginal adaptation of white and grey MTA and Portland cement. Aust Endod J 2007;33(1):2-6

8 Veríssimo DM, do Vale MS. Methodologies for assessment of apical and coronal leakage of endodontic filling materials: a critical review. J Oral Sci 2006;48(3):93-98

9 Solano F, Hartwell G, Appelstein C. Comparison of apical leakage between immediate versus delayed post space preparation using AH Plus sealer. J Endod 2005;31:752-754

10 Torabinejad M, Higa RK, McKendry DJ, Pittford TR. Effects of blood contamination on dye leakage of four root-end filling materials. J Endod 1994;20:159-163

11 Torabinejad M, Smith PW, Kettering JD. Pitt Ford TR. Comparative investigation of marginal adaptation of mineral trioxide aggregate and other commonly used root-end filling materials. J Endod 1995;21(6):295-299

12 Tam A, Yu DC. A new approach to restoring root-end cavity preparation in surgical endodontic procedures-a scanning electron microscopy study. Compend Contin Educ Dent 2002;23(12):1123-1126

13 Lee SJ, Monsef M, Torabinejad M. Sealing ability of a mineral trioxide aggregate for repair of lateral root perforations. J Endod 1993;19(11):541-544

14 Schmitt D, Lee J, Bogen G. Multifaceted use of ProRoot MTA root canal repair material. Pediatr Dent 2001;23(4):326-330

15 Camilleri J, Pitt Ford TR. Mineral trioxide aggregate: a review of the constituents and biological properties of the material. Int Endod J 2006;39(10):747-754

16 Torabinejad M, Chivian N. Clinical applications of mineral trioxide aggregate. J Endod 1999;25(3):197-205

17 Wucherpfenning AL, Green DB. Mineral trioxide vs Portland cement: two biocompatible filling materials. J Endod 1999;25:308

18 Estrela C, Bammann LL, Estrela CR, Silva RS, Pécora JD. Antimicrobial and chemical study of MTA, Portland cement, calcium hydroxide paste, Sealapex and Dycal. Braz Dent J 2000;11(1):3-9

19 Valera MC, Camargo CHR, Carvalho AS, Gama ERP. In vitro evaluation of apical microleakage using different root-end filling materials. J Appl Oral Sci 2006;14(1):49-52

20 Dammaschke T, Gerth HUV, Züchner H, Schäfer E. Chemical and physical surface and bulk material characterization of white ProRoot MTA and two Portland cements. Dent Mater 2005;21(8):731-738

21 Islam I, Chng HK, Yap AU. Comparison of the physical and mechanical properties of MTA and portland cement. J Endod 2006;32(3):193-197 
22 Danesh G, Dammaschke T, Gerth HUV, Zandbiglari T, Schäfer E. A comparative study of selected properties of ProRoot mineral trioxide aggregate and two Portland cements. Int Endod J 2006;39(3):213-219

23 Torabinejad M, Rastegar AF, Kettering JD. Pitt Ford TR. Bacterial leakage of mineral trioxide aggregate as a root-end filling material. J Endod 1995;21(3):109-112
24 Martell B, Chandler NP. Electrical and dye leakage comparison of three root-end restorative materials. Quintessence Int 2002;33(1):30-34

25 Soundappan S, Sundaramurthy JL, Raghu S, Natanasabapathy V. Biodentine versus mineral trioxide aggregate versus intermediate restorative material for retrograde root end filling: an invitro study. J Dent (Tehran) 2014;11(2):143-149 